\title{
CORRESPONDENCE
}

\section{RHEUMATOID FACTOR}

To the Editor,

Annals of the Rheumatic Diseases,

B.M.A. House,

Tavistock Square, W.C.1.

SIR, The recent paper by Ball (1962) tends to confirm the hypothesis put forward by Mellors and co-workers $(1959,1961)$ that rheumatoid factor (R.F.) may be synthesized in certain tissues such as synovial membrane and subcutaneous nodules. It also lends indirect support to the hypothesis suggested in my own recent paper (Gorringe, 1962) that the pulmonary lesions occurring in Caplan's syndrome may be sites of synthesis of R.F. To my knowledge this latter theory has not so far been put to the test and I should like to urge workers in this field not to miss the opportunity of doing this should a case of Caplan's syndrome come to autopsy or lung biopsy in the area where they work.

Dr. Ball's paper raises a much more important issue. He finds high R.F. levels in skin and has himself reported in a previous publication (Ball, 1952) the rarity of positive sheep cell agglutination (S.C.A.T.) reactions in cases where rheumatoid arthritis and psoriasis co-exist. Of the six cases with psoriasis in my own small series only those with pulmonary lesions showed a positive S.C.A.T. It would seem to follow that psoriatic skin differs biochemically from the skin of rheumatoid patients without psoriasis and this observation could form the basis of some important research. For a start three possible explanations of the observed facts should be investigated to see which is the true one:

1. The skin of normal rheumatoid arthritics synthesizes R.F. and the skin of psoriatics does not.

2. The skin of normal rheumatoid arthritics absorbs pre-formed R.F. to a certain extent but not sufficiently to reduce the plasma level below the diagnostic limit, whereas psoriatic skin achieves more complete absorption of the factor.

3. The presence of psoriasis is associated with a generalized depression of R.F.-producing capacity in other tissues as well as skin.

My own observation that patients with Caplan's syndrome and psoriasis have a positive S.C.A.T. seems to favour the first of these three possibilities.

Yours faithfully,

\section{J. A. L. Gorringe,} M.D., M.R.C.P.(Ed.), Director, Department of Clinical Inves-

Staines Road, tigation, Parke, Davis and Company.

HOUNSLOW,

MidDLESEX.

December 6, 1962.

\section{REFERENCES}

Ball, J. (1952). Ann. rheum. Dis., 11, 97. (1962). Ibid., 21, 272.

Gorringe, J. A. L. (1962). Ibid., 21, 135.

Mellors, R. C., Heimer, R., Corcos, J., and Korngold, L. (1959). J. exp. Med., 110, 875.

- Nowoslawski, A., and Korngold, L. (1961). Amer. J. Path., 39, 533.

\section{NEDERLANDSE VERENIGING VAN RHEUMATOLOGEN}

In memory of Dr. Jan van Breeman, the Nederlandse Vereniging van Rheumatologen has decided to institute a biennial oration by a prominent rheumatologist, to whom the van Breemen Medal will be awarded. The first oration was given on November 3, 1962, by Dr. Jacques Forestier of
Aix-les-Bains, who took as his subject: "Évolution de la thérapeutique de la polyarthrite chronique évolutive de 1930-1960 (chrysothérapie et corticosteroidthérapie)." 